\title{
Panpsychism, pan-consciousness and the non-human turn: Rethinking being as conscious matter
}

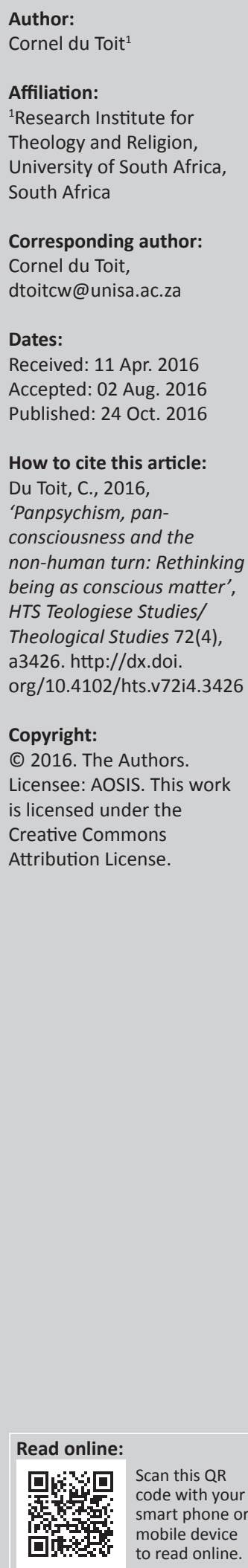

It is not surprising that in a time of intensified ecological awareness a new appreciation of nature and the inanimate world arises. Two examples are panpsychism (the extension of consciousness to the cosmos) and deep incarnation (the idea that God was not only incarnated in human form but also in the non-human world). Consciousness studies flourish and are related to nature, the animal world and inorganic nature. A metaphysics of consciousness emerges, of which panpsychism is a good example. Panpsychism or panconsciousness or speculative realism endows all matter with a form of consciousness, energy and experience. The consciousness question is increasingly linked to the quantum world, which offers some option in bridging mind and reality, consciousness and matter. In this regard Kauffman's notion of 'triad' is referred to as well as the implied idea of cosmic mind. This is related to the notion of 'deep incarnation' as introduced by Gregersen. Some analogical links are made between panpsychism and deep incarnation.

\section{Introduction}

\section{The matter of consciousness and consciousness as matter}

Panpsychism is reviving in the twenty-first century. This revival can be justified by, among other things, the ecological turn and developments in quantum research and particle physics.

Not all speculation is worthless and the difference between 'soft' speculation and scientific conjectures may often be a thin line, metaphorically expressed by the idea of a gap-filler (see the German Lückenbüsser or Stellvertreter). This article contains some speculation that is the inescapable outcome of dealing with speculative realism or panpsychism. ${ }^{1}$ Panpsychism relates to the basic mind-brain, matter-thought dualism. We may, however, gain valuable and necessary insight through this exercise even if it means that previously held 'certainties' may become so contaminated by the present topic that we have to give up the idea that we enjoy firm and certain knowledge.

We know that consciousness needs a body to operate and mind cannot exist without brain. But panpsychism sees consciousness as typical of all matter, whether it has a brain or not, which in a way turns materialism on its head. Materialism in its strict sense reduces everything to matter. ${ }^{2}$ Even mind is a consequence of matter or simply matter in the mode of consciousness. Panpsychism turns this around. Basic to all things that exist is consciousness.

Panpsychism can be seen as new animism or new materialism or speculative realism. It also fits into absolute idealism or what can be called panconsciousness. Bertrand Russell noted as long ago as 1925 that physics is no longer materialistic in the old seventeenth-century sense of the word, holding matter as permanent substance. The notion of force, for example, implies allowing particles of matter to interact with each other through void space without any material link (see Strawson 2015b:168, n22). Russell rejected materialism in name, saying 'matter has become as ghostly as anything in a spiritualistic séance - it has disappeared "as a thing" and has been 1.As I was finishing this article the first 2016 edition of the CTNS journal Theology and Science appeared with the theme The cosmic mind:
Entanglement over physics, panpsychism and the Trinity. The volume deals with the contribution of Stuart Kauffman, Cosmic mind? and
a number of responses to it. The editor, Ted Peters, finds Kauffman 'delightfully speculative' (Peters 2016:2). But he wants more: 'On
the one hand, Kauffman's speculations rightfully open windows in the physical world to what lies beyond materiality: mind,
consciousness, intelligence, freedom. On the other hand, his speculations stop there. His windows do not open toward a transcendent
God' (Peters 2016:4). This is another topic and this possibility is not entertained in the contribution.

2.Typical of the new emphasis on matter is that matter is not as easy to grasp as we thought. Clark (2010:34), with reference to the Enneads of Plotinus, puts it powerfully: 'Notoriously, matter is almost as difficult to conceptualize as the One itself. None of us ever encounters Matter directly, but only the golden chains that bind it. Soul (both the Soul of the All, and the Soul of each of us) creates the living world: without it there would only be "the darkness of matter and non-existence," and "what the gods hate"'. 
replaced by emanations from a locality' (Strawson 2015b:167168). We know from particle physics today that matter is balanced by anti-matter and that particles fluctuate in and out of existence all the time ${ }^{3}$ (see Carroll 2012).

The notion of panpsychism seems to gain momentum and it is worth revisiting it as expression of the so-called Speculative Turn that seems to characterise the twenty-first century. Panpsychism must be seen against the background of new developments and how these feature in pseudo-science, religion, the New Age movement and popular culture. It is captured by the notion of a non-human turn, which describes developments from the last decades of the twentieth century. For Grusin (2015:ix-x) the non-human turn insists that 'we have never been human'. The human has always coevolved, coexisted or collaborated with the non-human. The human is characterised precisely by this lack of distinction from the non-human.

Grusin (2015:viii-ix) mentions the following developments that contributed to the non-human turn: actor network theory (see Bruno Latour's project that focused on technical mediation, non-human agency and the politics of things); affect theory; animal studies; the assemblage theory of Gilles Deleuze and Manuel De Landa; cognitive and brain sciences; the new materialism in feminism and Marxism; the new media theory and its focus on technical networks, material interfaces and computational analyses; varieties of speculative realism including object-oriented philosophy, new-vitalism and panpsychism; and systems theory, especially in its technical and ecological manifestations.

Without pursuing these points the following can be added. Although some of the claims made may border on the fictitious, they presently enjoy attention:

1. With the latest developments in particle physics we have entered a new era where the distinction between physics and metaphysics (including religion) is not so clear any more. Science has to deal increasingly with metaphysical questions. ${ }^{4}$ For example: the relation between being and non-being (matter or anti-matter); the question of the nature of being (field theory); unity and dualism (symmetry and the need to break it down); the importance of 'nothingness'5; divisibility and unity; and the role of different, interacting forces. Without the opposites no movement, formation of matter, development of galaxies, solar systems and ultimately life itself would have been possible. ${ }^{6}$ There are also the well-known metaphysical issues such as chance, creativity, matter-energy, information, the dialectic between

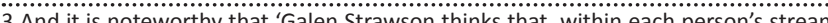
of consciousness, little transient selves constantly wink in and out of existence, none of them lasting for more than an hour or so' (Holt 2012:257).

4.The Large Hadron Collider at CERN can advance philosophy. It raises new questions: what are the methods of acquiring knowledge, what is the role of models and how does the intricate relationship between theory, computer simulations and experimental data work (see Krämer 2015; Carroll 2012)?

5.See Holt (2012:41-62).

6.The 2015 work of Roger Trigg, Beyond matter: Why science needs metaphysics makes an important contribution to this debate. It argues that the purpose, possibilities and limitations of science can only be meaningfully valued from a (metaphysical) position outside science. reductionism and emergence and the like. A new kind of metaphysics challenges philosophy: 'Metaphysics is based on observation, and today's science provides experiments that lead to challenging philosophical questions beyond the scientific realm and may inspire metaphysical reflection' (Adams \& Suarez 2013:286).

2. On the quantum level the double slit experiment has indicated the role of the conscious observer in determining the collapse of the wave function, which is determinative in grappling with the quantum world and is elaborated upon when we focus on Kauffman's view below.

3. We know that autopoietic systems are operative in the biological sphere and physicists claim that the universe itself is self-explanatory. There is no need for a supernatural force to explain it. Nevertheless, the unfolding of the universe and the development of life on our planet are so fabulous that many cannot but posit a divine architect. Science rejects any intelligent designer. The universe itself has become intelligent, conscious and self-reflective in thinking human beings. The notion of consciousness is metaphorically transferred to the universe by panpsychism.

4. On an ecological level the planet earth is seen as one big living organism, Gaia. The geosphere, lithosphere (ground), hydrosphere, atmosphere, biosphere, stratosphere and noosphere all interact as part of this living organism. As a living organism there will be levels of awareness and consciousness that characterise the various spheres.

5. The universe is alive. On this level cosmic consciousness emerges. We know that human life consists of elements that were formed in the stars and that our planet and galaxy would not exist were it not for developments on a much larger and older universal scale. We are part of this history, which explains us. The information metaphor plays a crucial role in understanding this. ${ }^{7}$

6. O'Murchu (2004:35) refers to the model of the brain as a hologram. Only such a model makes sense of the holistic universe that exists, according to his view. This idea falls back on the notion of David Bohm that all that unfolds before our eyes is only a small part of an unbroken wholeness (O'Murchu 2004:61-62). Bohm found that electrons, once introduced into a plasma with a high density of electrons and positive ions, started behaving as if they were part of an interconnected whole. This idea was extrapolated to include all reality. 'Wholeness was, in some way, the primary reality. It was equally powerful everywhere. It did not diminish with distance. It expressed something of the identity of reality that could never be understood by studying the individual wholeness' (O'Murchu 2004:62). This idea is in line with the quest to find one substance or entity that explains everything.

7. We know that energy and matter are reversible and that consciousness can be seen as a form of energy. Does this make consciousness and matter to some extent reversible? We know that all matter is imbued with information. If the information inherent in a specific kind of matter (the atomic and molecular structure) changes, then the matter will change as well.

7.Internet traffic is both human and non-human. Technical mediation is non-human (see Grusin 2015:xiv). 
8. On the level of human-animal interaction, research has indicated interconnectedness at various levels. Research on the great hominids can be singled out as a factor that contributed much to respect for all animals, and the development of animal rights in some countries. The new appreciation for environmental ethics and the development of a creaturely theology (see Deane-Drummond 2009) have contributed to eco-awareness. ${ }^{8}$ The so-called Cambridge Declaration of 2012 stated that animals have consciousness, which is an extension of consciousness beyond human confines.

9. On the level of health and medical research, humans may in future reprogram their genes to attain immortality. Artificial limbs may be linked to the brain to operate like normal organic limbs. We know that we share our genes to various degrees with other organisms and that all life on earth is related.

10. We will soon be able to develop supercomputers that will far exceed the human brain's capacity. These supercomputers may eventually start to think for themselves, develop programmed emotions and reach a state of 'mind' similar to consciousness.

11. On a religious level the notion of 'deep incarnation' stresses the importance of God's saving presence in nature. This importance elevates nature, along with humans, into the soteriological sphere of God's saving and regenerating grace.

12. The notion of panentheism unifies all creation in God and this is not that different from the notion of consciousness as a unifying principle. The ubiquity of God implies, like the ubiquity of consciousness, the omnipresence of the mental. Panpsychism is in a sense a secular version of panentheism. 'Everything is mind', or in a different mode 'everything is in God'. To be in God affects the dwellers and endows them with some form of awareness of 'being in God'.

The speculative basis of most of these points cannot be denied. The question is whether science will eventually provide sufficient reasons and examples to ground such claims or to disprove them convincingly. Along with the increase of secularism there is a new interest in the value of nature and natural things, especially in the field of secular spirituality.

\section{What is panpsychism?}

Panpsychism considers mind as fundamental to all things. Various versions of panpsychism have been articulated in the past by classical thinkers such as Spinoza, Leibniz, Fechner, Lotze, Pierce, James, Bergson, Whitehead, Hartshorne and Sprigge (see Basile 2010:96; Barnard 2011:118). Without going into this history, we can briefly note that deism was the generic position in the Aufklärung, and panentheism became the common point of reference during the eighteenth century. Darwin's evolutionary model became accepted in biology

8.See also The Cambridge Declaration on Consciousness (See Low 2012). The Confession written by Philip Low and edited by Jaak Panksepp, Diana Reiss, David Edelman, Bruno Van Swinderen, Philip Low and Christof Koch), which acknowledged that animals have consciousness. The Declaration was publicly proclaimed in Cambridge, UK, on 7 July 2012 at the Francis Crick Memorial Conference on Consciousness in Human and non-Human Animals, at Churchill College, University of Cambridge, by Low, Edelman and Koch. The signing ceremony was memorialised by CBS 60 Minutes. and continued the Platonic organic metaphor based on the empirical sciences (Cooper 2006:121). Plato regarded the universe as an intelligent living being (see Timaeus). This idea was fuelled by Darwinism, the biological design of JeanBaptiste Lamarck, the brilliant work of biologists such as Valera and Maturana and the notion of self-making (autopoietic) systems, which emphasises some form of cognition, will and intention in very primal matter. Common to these questions is the relation between organic and inorganic matter (mind and matter) and the forces that determine this.

Before the science revolution mind and matter were not strictly separated. The notions of animism, vitalism (see Bergson [1859-1941] in Barnard (2011), which would come much later), pantheism and panentheism attribute some kind of force (life) to matter. In pantheism all matter is God and God is in all matter. In panentheism all matter exists in God. In both cases the relationship with God affects the matter in one way or another. Only deism separates God from matter (see also Plotinus's strict separation between matter and spirit [logos] in his Enneads). The question is, to use panentheism as an example: what difference does it make to matter to reside in God or not to reside in God? If there is no difference for matter between being in God (en theos) or being not in God (quod non est in Deo), the whole notion of 'being in God' becomes insignificant. The doctrine of God's preservation (preservatio Deo) means that God upholds and governs everything, including matter, as well as all miniscule components and circumstances it entails (atoms, quarks, fields, etc.). If God 'withdraws' his hand all crumbles to dust. God created ex nihilo and if he withdraws his hand (his presence) everything will collapse (venire ad nihilum); this can only mean in the case of matter that collapsing into nothingness means nothing to it [matter] and has implications only for the observer (humans or God); or it does have implications for matter, which implies some form of awareness of the difference between being and not-being, which in turn implies some form of awareness or protoawareness. It boils down to the scientific realist position that assumes that reality exists objectively and independently of perception or measurement, which may be true, but if it is true reality is insignificant. Perhaps this is why brute matter has an 'inherent' drive or will to develop into consciousness. Hence, the suggestion that matter wants to be known has a drive to self-consciousness. Humans are composed of brute matter and emerged from brute matter into self-conscious, thinking matter. We are thinking matter simply because we exist in the right combination of matter.

The reformed notion of God's preservatio implies that he has a special relation with matter (creation). Romans 8 personifies nature, which waits in anticipation upon the action of God. No I-thou relation is possible without some form of awareness on both sides. Is this valid in the case of an I-it relationship as well? Matter can be imbued with sentiment, may carry symbolic worth or be of special value to us. Sentimental value attached to things relates to the experiential history we remember in which a specific object had a special place. But that is because the object mediates relation with something or 
somebody else (a loved one). I can care for inanimate matter but without the possibility of a mutual relationship. I may care for my car but it is unaware of me. We know that we get attached to things, to objects, artefacts, places, images. Inherent in this sentiment is the unexpressed 'feeling' that the dead object knows and senses this. The recognition of 'your property' in a criminal case where your goods have been stolen confirms this relationship. You recognise the stolen item as bound to you, as 'your property'. You affirm attachment. The thief does not enjoy this attachment history. It is only possible for the 'lawful' owner. The thief's attachment will always be an 'attachment' to stolen property. This example concerns the existential level of human beings' attachment to things. The question is whether one can think in terms of a mutual relation that implies some form of 'awareness' or of 'being affected' on the part of the thing.

Hegel indicated that a mutual relation can exist between conscious human beings and inanimate matter. Humans learn from 'inanimate, dead matter' when they try to figure it out or study it. In the process of knowledge acquisition both parties change - the human investigator as well the investigated object, and this is similar to what happens between two intelligent human interlocutors. But this is once again seen from the side of the human subject. The inanimate object is 'not aware' of the change that has taken place through this experience. Or is it? Without going into any detail, we know that the 'double slit' experiment has proven sufficiently that a particle (photon and inanimate matter) responds to the observation of an observer, which changes its state from a wave to a particle.

Seager and Allen-Hermanson (2015) refer to the division between mind and matter inaugurated by the science revolution in the fifteenth century and the resultant choice to give preference to matter as the object of science. 'It was the modern "mechanistic" picture of the world inaugurated by Galileo, Descartes and Newton which put the problem of the mind at centre stage while paradoxically sweeping it under the rug' (Seager \& Allen-Hermanson 2015:6).

Thus, everything that could not be accounted for in terms of the interactions of simple material components was conveniently labelled a 'secondary quality' inhabiting not the 'real' world but merely the conscious mind (the classical example is colour, which was banished from the world of matter and replaced with the mind mechanisms that make us experience colour). The mind was not to be trusted and physics would reveal how the world 'actually' is. The world was made safe for physics.

George Berkeley (1689-1753) denied that anything exists or could conceivably exist except insofar as it was consciously experienced. Berkeley's notion of esse est percipi (being is sensual perception) means that ontology is determined by our senses $^{9}$ and nothing exists except sentient experience. This is

9.The content of consciousness depends on intact human physiology where all reality is mediated through our five senses. But the senses cannot be singled out as the is mediated through our five senses. But the senses cannot be singled ou only access to reality. Alva Noe (quoted in Aizawa 2010:263) proposed an extended consciousness that is not exclusively determined by brain physicality but by ou broader biological correlates. Consciousness is not something the brain achieves on subjective idealism. This, coupled with the 'doctrine of ideas' - that what we immediately perceive is restricted to our own states of consciousness - leads him to the conclusion that all physical objects are systems of possible conscious perceptions, which means that matter is not mind-independent. Unlike Leibniz or Spinoza, there was for Berkeley no correspondence between the order of the material world and the mental order (Seager \& Allen-Hermanson 2015:7).

Panpsychism had its greatest flourishing in the nineteenth century due to the prominence of idealism; panpsychism is a kind of new vitalism. Henri Bergson had his own version of panpsychism (Barnard 2011:118). Gustav Fechner (1801-1887) endorsed a 'world-soul' or 'world-mind' of which everything is a part without explaining how 'world-soul' itself came into being. Schopenhauer (1788-1860) saw everything as conscious but not necessarily as alive. Other prominent nineteenth-century exponents of distinctive forms of panpsychism were Wilhelm Wundt, Rudolf Hermann Lotze, William James, Friedrich Paulsen, Eduard von Hartmann, Ferdinand C.S. Schiller and Ernst Häckel (Seager \& AllenHermanson 2015:8).

Alfred North Whitehead (1861-1947) is the twentieth-century champion of panpsychist philosophy. He saw events (or items that are more event-like than thing-like) and the ongoing processes of their emergence and disappearance as the core feature of the world, rather than the traditional triad of matter, space and time. His panpsychism arises from the idea that the elementary events (occasions) that make up the world partake of mentality in terms of notions such as creativity, spontaneity and perception. For lifeless matter these functionings impede each other and average out to produce a negligible total effect. Whitehead's panpsychism faces the same objections as any other version and stems from the same basic anti-emergentist intuition. With his emphasis on the vitality and spontaneity of nature, Whitehead represents a culmination of nineteenth-century panpsychist thinking, and (probably not coincidentally) its presentation was pretty much simultaneous with the culminating development of a robust and serious emergentism (Seager \& Allen-Hermanson 2015:10).

After the publication of Whitehead's panpsychist Process and Reality (1929) and the publication of C.D. Broad's emergentistoriented Mind and Its Place in Nature there was little interest in either panpsychism or emergentism. ${ }^{10}$ Is there presently a revival of panpsychism? Sheldon (2015:203) refers to the 'speculative turn' and sees it as a development of 21st century that is a deliberate counterpoint to the 'linguistic turn' of the previous century. Characteristic of the speculative turn,

(footnote 9 continues...)

its own. Consciousness is determined by the joint input of brain, body and world (see Aizawa 2010:263). For Noë, consciousness is achieved in action, like a work of improvisational music. It emerges as the action unfolds (Aizawa 2010:264). The outside world and environment determine predominantly what goes on in outside world and environment determine predominantly what goes on in consciousness, but this is only possible because of the vital role played by brain
physicality.

10.Strawson rejects 'brute emergence', which he says rests on scientific reductionism or what can be called "smallism" - the view that all facts are determined by facts or what can be called "smallism" - the view that all facts are determined by facts
about the smallest things, those that exist at the lowest "level of ontology" (Shaviro 2015:33). 
according to Sheldon (2015:205), is an object-oriented ontology focusing on the substratum of objects, the thing in itself - not the historical conditions of its emergence. Shaviro (2015:20) shares this sentiment: 'Panpsychism seems especially relevant today, in light of the "nonhuman turn" in critical discourse, and the new philosophical movements that are gathered under the rubric of "speculative realism"'.

The most prominent explicit defenders of panpsychism at the present time are Galen Strawson, David Griffin, David Ray Griffith, David Chalmers, Thomas Nagel, William Seager, David Skrbina, Keith Ward, Bernardo Kastrup and the late Timothy Sprigge. In Basile's view it cannot be rejected as an historical anomaly (2010:96). Still, most philosophers devote not more than a few adverse sentences when dealing with panpsychism, preferring instead to cling to materialism (Barnard 2011:119).

\section{Sprigge and Nagel and the 'what-it-is-like-ness' of subjective inwardness}

Thomas Nagel sees panpsychism as 'the view that the basic physical constituents of the universe have mental properties, whether or not they are part of living organisms' (Shaviro 2015:19). In opposition to idealism and Cartesian dualism, eliminative physicalism like panpsychism maintains that thought is neither merely epiphenomenal ${ }^{11}$ nor something that exists in a separate realm from the material world (Shaviro 2015:19-20). Nagel's article was well received and is pivotal to understanding the interest in panpsychism. Nagel got his idea from Galen Strawson (1994:81ff).

Timothy Sprigge independently came to the same conclusion as Thomas Nagel about the question of consciousness by arguing that there must be an answer to what it was like being her or it at that time (McHenry 2010:7). According to McHenry (2010:11), Sprigge captured the essence of consciousness as subjective inwardness. From this base he moved on to construct his panpsychist ontology in which consciousness or sentience is omnipresent in the universe. For Sprigge, human consciousness is the noumenal reality behind phenomena perceived as physical reality. ${ }^{12}$ Nature does not only exist as an object for human consciousness or as a system of possible sensations on our part, says Sprigge. For him nothing can exist if it is not experience (McHenry 2010:14).

Nagel's article What is it like to be a bat? (1974) drew some attention with its statement that an organism can have a conscious state only if there is something that we can relate to being that organism. Consciousness, in this view, has an essentially subjective character, a what-it-is-like aspect. Nagel moves from the problem of access (epistemology) to the problem of being (ontology) (Shaviro 2015:25). This subjective aspect of consciousness cannot be captured by any familiar

11.Epiphenomenalism accepts that consciousness emerges from matter, but denies that minds exist independent of matter.

12.Kauffman's hypothesis (2015:298) links consciousness to quantum processes: 'quantum measurements in the brain, perhaps in protein neurotransmitter recepto molecules in synapses, are associated with experience, consciousness, qualia'. analysis of the mental state or by any explanatory system of functional or intentional states, since these could be ascribed to robots or automata that behave like people though they experience nothing. Nagel says that it is useless to base a defence of materialism on any analysis of mental phenomena that fails to deal with the subjective character of entities (1974:2). Bat sonar, for example, is not similar to anything we can experience or imagine. No method will allow us to extrapolate to the inner life of the bat from our own case (Nagel 1974:2). The problem we are faced with is that what we perceive through our senses is already processed reality. The end product of seeing or hearing or feeling something is because of the intricate bodily processes that make this possible. But we do not have access to these processes and the processes themselves do not 'feel', 'see' or 'smell'; they issue in feeling, seeing and smelling. Nagel expresses the same sentiment when he says 'If mental processes are indeed physical processes, then there is something it is like, intrinsically, to undergo certain physical processes. What it is for such a thing to be the case remains a mystery' (1974:5).

These ideas influenced contemporary philosophers and cognitive scientists, who hold the following theses (Hacker 2013:50): (1) An experience is a conscious experience if and only if there is something it is like for the subject of the experience to have that very experience. (2) A creature is conscious or has conscious experience if and only if there is something it is like for the creature to be the creature it is. (3) The subjective character of the mental can be apprehended only from the point of view of the subject.

\section{Shaviro (2015) remarks:}

'What it is like to be a bat' is not a Something: for it is not specifiable as a thing at all. But the bat's inner experience is not a Nothing either. This means that it is indeed 'like something' to be a bat, even though 'what it is like' is not $a$ Something. ${ }^{13}$ (p. 30)

In this regard Strawson's panpsychism makes for him the most sense, as he considers mentality of some sort more certain than the existence of anything else, whether we call this mentality experience, consciousness, conscious experience, phenomenology, experiential 'what-it's-like-ness', feeling, sensation or explicit conscious thought (Shaviro 2015:31). Strawson echoes Descartes' cogito without the dualism. We must reject the notion that the physical is essentially non-experiential. If we reject dualism and supernaturalism, then mentality itself must be entirely physical (Strawson 2015a:32).

But only a human can pose the question 'what is it like to be a bat?' We have no evidence that a bat wonders what it is like to be a bird or an aeroplane.

\footnotetext{
13.There is transitive and intransitive consciousness. Intransitive consciousness simply denotes that you are awake (not asleep) or conscious (not comatose). Consciousness is to be awake and not asleep, aware and not unconscious, but consciousness is not equivalent to thinking. Hacker (2013:20-21) makes the important point that ther is no such thing as being conscious of one's consciousness. To become and then to is no such thing as being conscious of one's consciousness. To become and then to be conscious of something is not to perform any kind of act. To become conscious is not to pay attention to or focus on something. Neither is being conscious the acts of thinking, reflecting, deciding, etc. Consciousness is not an activity, but something hat happens to you. Consciousness is that which 'moves' across your mind something that strikes you or something that you become aware of. Consciousness is not a form of knowledge or something you can be trained in. You can only be trained to be more receptive, sensitive (Hacker 2013:26).
} 
An important point to note is that it is our current concept of matter as that which is wholly and utterly non-experiential (non-conscious) which makes it impossible to understand how mind, the experiential and conscious, could emerge from it (see Basile 2010:103).

\section{Pan-consciousness, panpsychism, pan- experientialism}

There is no physical evidence that inanimate objects are conscious. To allot consciousness to 'dead' matter implies a metabasis eis allo genos, an unwarranted transition into another genus. It makes sense to ask what it is like to be a bat but not what it is like to be a stone. A stone is inanimate matter and has no consciousness, awareness or any feeling of presence. To aver that an inanimate thing has some form of awareness, feeling or presence is animism and we outgrew that long ago. But then we are not stones, although we are made up of inorganic matter. But neither can we know for certain that other people are really conscious because we have no access to their inner selves. We do recognise behaviour in other humans similar to our own and we do recognise in some mammals emotions similar to our own.

The radical jump made by panpsychism is the formulation of a naturalised metaphysics where all objects of nature are themselves subjects of experience. Panpsychism is all about the extrapolation of consciousness (experience) to non-braindependent entities. This transcends the notion that consciousness is the direct and exclusive consequence of brain physicality. Inorganic matter, i.e. nature, is seen as alive to various degrees. This boils down to a naturalisation of mind and a mentalisation of nature (McHenry 2010:15). Intuitively we feel that inanimate reality cannot be alive or experiential. To be experiential means to be able to feel, think, control or process what happens to you. It presupposes some form of a 'self'. It seems plausible that different levels of consciousness or awareness characterise most life-forms. Shaviro (2015) expresses this well:

there is good scientific evidence that all living organisms, including such brainless ones as plants, slime molds, and bacteria, exhibit at least a certain degree of sentience, cognition, decision making, and will. But what about things that are not alive? How many non-stoned people will agree ... that a rock has a mind? (p. 22)

One possibility is to extend the notion of 'experience', as it is used by panpsychism, to such a level that it is not understood in terms of human perception. Human experience is impossible without our senses, and non-living matter is senseless as far as we know. Royce tries to make sense of this with his notion of apperceptive time. What we perceive as inorganic nature is not dead, 'experienceless' matter, but nature 'alive' in various degrees (see McHenry 2010:15).

To experience anything one needs the mediation and operation of one's senses. How can inanimate matter sense anything without having senses? This is 'possible' through Whitehead's understanding of 'prehension'. Prehension is non- sensory perception and all experience begins with this. Griffin (1989:24) explains that Whitehead distinguishes moving from stationary things. In a sense our body 'knows' before we know. Our senses convey light, sound and smell to our brain, which interprets them on a different level. On a primary level our bodily senses prehend before the brain apprehends. Clark (2010:22) reminds us: 'Most of the world, including our bodies, is managed by "Nature," without any help from us, and we would do better not to get involved with it'.

We attribute mind or soul to moving things and this entails experience, history, even memory. A rock is stationary and as such has no experience. But the molecules, atoms and other subatomic particles of which the rock consists are not devoid of experience. The resulting position can be called process philosophy's version of 'panexperientialism', which is applicable to all individuals but not to all things whatsoever (Griffin 1989:24).

One could also think of Whitehead's concept of causal efficacy as the basic mode of perception in nature:

A jellyfish advances and withdraws, and in so doing, exhibits some perception of causal relationships with the world beyond itself; a plant grows downwards to the damp earth, and upward towards the light. There is thus some direct reason for attributing dim, slow feelings of causal nexus, although we have no reason for ascription of the definite percepts in the mode of presentational immediacy ... As we pass to the inorganic world, causation never for a moment seems to lose grip. (Whitehead quoted in McHenry 2010:15)

For Sprigge innumerable streams of experience exist independently of human and animal consciousness. The inanimate world is nothing but sentient experience (McHenry 2010:15). This means that terms such as 'experience', 'sentience', 'consciousness' are applied to inanimate nature (McHenry 2010:17). In the case of humans, consciousness is unthinkable without language and various types of symbolic representation of our experience (Hacker 2013; McHenry 2010:9). In the case of non-human reality various options are available, ranging from some form of consciousness and awareness on the level of animals and living organisms to some form of 'proto-consciousness' on an inanimate level.

Panpsychism depends to a large degree on the fact that we do not really know what consciousness is, how to define or explain it. ${ }^{14}$ We may think that we know what goes on in our conscious mind, although the subconscious forms $90 \%$ of our minds. Holt (2012:193) remarks that the one part of reality that we know without scientific mediation is our consciousness. We have direct access to it from within the inner world of the mind. The possibility this raises is that maybe the part of reality that we know indirectly through science has the same inner nature as the part we know through conscious introspection. 'In other words, maybe all of reality - subjective and objective - is made out of the same basic stuff'. This was the conclusion reached by Bertrand 14.In this regard Strawson (2015:9) says that physics cannot characterise the non-
structural nature (i.e. the intrinsic experiential-qualitative nature) of concrete reality at all. 
Russell in The analysis of matter, and Arthur Eddington said (quoted in Holt 2012:193) in The nature of the physical world that 'the stuff of the world is mind-stuff'. This means that consciousness pervades all of physical nature, and subjective experience is not confined to human consciousness but is present in every piece of matter (Holt 2012:193). The argument runs as follows: the properties of a complex system such as the brain depend on the ultimate constituents of the brain, which must have these subjective features themselves that in the right combination issue in our inner thoughts and feelings. The basic particles such as electrons, protons and neutrons that make up our brains are similar to those that make up the universe. The entire universe thus consists of little bits of consciousness (Holt 2012:194). All of this presupposes that consciousness is an enigma that humans 'participate' in consciousness but that the consciousness realm exceeds human experience. This position represents a kind of consciousness ontology where all reality forms part of the panconscious expanse.

The moment consciousness becomes the ontological basis of the universe, the notions of design and teleology come into play. Keith Ward (2010) exemplifies this when he says:

conscious personal life and the material structure of the universe fit together in a coherent way if we suppose that the physical universe has the purpose of producing personal consciousness as the natural realization of its inherent and original capacities. (p. 87)

This implies some form of intelligent design. How can the universe 'act', 'plan', 'have in mind'? Ward explains:

Even the laws of nature exist for a reason, and the best reason is that they exist for the sake of desirable goals which the universe may realise. We are then to think of a primordial mind that can envisage and evaluate possible goals and bring them about intentionally. (Ward 2010:185)

Consciousness cannot be introduced into the universe as a foreign element. It emerges from the universe and may even be an inevitable 'outcome' in most universes, but to say that the universe has the forming of consciousness 'in mind' presupposes an intelligent designer behind all. There is a theory that material under the influence of entropy and increasing complexity drives towards the formation of organic material as an outcome of the movement of energy. A New Physics Theory of Life has proposed that life exists because the law of increasing entropy drives matter to acquire life-like physical properties. ${ }^{15}$

An interesting point in panpsychism is that consciousness is not made up of particles that come together and are arranged in the right relation with the resultant emergence of consciousness. The particles are themselves bits of consciousness. Panpsychism cannot really cope with the

15.From the standpoint of physics, there is one essential difference between living things and inanimate clumps of carbon atoms: the former tend to be much better thing a at capturing energy from their environment and dissipating that energy as heat The formula, based on established physics, indicates that when a group of atoms is driven by an external source of energy (like the sun or chemical fuel) and surrounded by a heat bath (like the ocean or atmosphere), it will often gradually restructure itself in order to dissipate increasingly more energy, which could mean that under certain conditions, matter inexorably acquires the key physica attributes associated with life (Wolchover 2014). problem of the unity of consciousness. If the thermostat is conscious, are its parts conscious as well? Is there a separate consciousness to each screw and molecule? If this is so, what is the unifying factor uniting these bits of consciousness to one unit (see Basile 2010:94)?

A single ontology underlies the subjective information states in human minds and the objective information states of the physical world. Hence Chalmers' slogan 'Experience is information from the inside; physics is information from the outside' (Holt 2012:194). This rules out emergence as the possibility of creating a 'higher' level of existence from 'lower' preconditions. But how do little bits of mind-stuff combine to form a bigger mind, such as the human brain, and how can many 'small' consciousnesses unite to form one consciousness? Here quantum entanglement may come to the rescue, says Holt, where distinct particles, no matter how far separated from each other, lose their individual identities and act as a unified system (Holt 2012:195). De-coherence or the collapse of the Schrödinger wave does not happen only when observed or measured. De-coherence also takes place when particles entangle with the macro-world. We do not yet know all the processes that play a role during the double-slit experiment. There is also a borderline area where Newtonian laws kick in on a macro-level. How quantum rules translate into the macro-world is still unknown.

\section{Galen Strawson's take on panpsychism}

Galen Strawson is the son of the renowned analytical philosopher PF Strawson and one of the best present-day campaigners of panpsychism. He describes himself as a stuff monist, a materialist or physicalist. He believes that there is only one thing in concrete reality (in spacetime/universe) and that is consciousness (2015:7-8).

He explains the basic tenets of panpsychism through the following well-known German distinctions: Stoff ist Kraft; Wesen ist Werden; Dasein ist Sosein; and Ansich ist Fürsich. Sein ist Bewusstsein.

1. Stoff ist kraft (matter is energy): All physical stuff is energy in one form or another; therefore, Strawson believes that all energy is an experience-involving phenomenon (Strawson 2015:1; Shaviro 2015:24). Strawson uses the concept 'energy' in the Heisenbergian sense of energy as substance, and the characteristic of substance is that it acts. What does not act does not exist. For Strawson energy also explains causation. The causal laws of the universe describe the particular form or mode of energy as exists in the universe (Strawson 2015:2). The dictum 'all matter is energy' allows the reduction of being to a single unit (energy). From here it is a short step to link energy and consciousness in some way and to reduce all being to consciousness. But the concept of 'energy' or 'consciousness' acts as common denominator and does not reflect the present state of all being.

Sein ist raumsein. Being is spacetime: Spacetime is energy. Spacetime is the existence of the four basic forces in the universe as well as the Higgs field. The fields or just one field is simply a matter of the existence of energy. 
2. Wesen ist Werden (being is becoming): Strawson (2015:3) considers a processual view of reality as mandatory: being is process, doing activity. Wirklich ist was wirkt (Strawson 2015:3). Being is its acting. The actual is what has an effect. But being here is not restricted to the tangible: it may be energy as well. What are the implications of this? 'Werden' in a sense describes 'Wesen' and typifies its mode of existence. But 'Wesen' is not one in its present state in reality; neither is 'Werden' one.

3. Dasein is Sosein (being is quality). There is no metaphysically fundamental distinction between substance and attribute (Strawson 2015:3). Being always appears in a specific mode or presentation. To be is to be somehow, something, somebody. Strawson (2015:3) formulates: 'An object considered at any time. $\mathrm{t}=$ its (intrinsic instantiated concrete) propertiedness at $t^{\prime}$. Kant formulated that accidents or properties are not subordinated to substance, but the specific mode of that substance and a certain time (see Strawson 2015:5).

4. Ansichsein ist Fürsichsein (in-itself is for-itself). For a being to be 'for itself' is for there to be something it is like to be it, experientially. It is for it to be a conscious or experiencing being (Strawson 2015:5) (see Nagel's bat example). Strawson translates this into being is mind - being is thus consciousness or experience. This is panpsychism or panexperientialism (Strawson 2015:5). Being is experience and this is equivalent to being is consciousness (Sein ist Bewusstsein). Skrbina argues that there is no difference in kind between a human and a rock. The rock experiences the world and we experience the world. From 'experience' panpsychism moves to 'consciousness' (Basile 2010:97). Strawson (1994:2) uses the term 'experience' for consciousness. Experience is sensorily contentful, and as 'real as a rock'. 'The experience of an experiencing being is everything about what it is like to be that being, experientially speaking, from moment to moment as it lives its life' (Strawson 1994:3). Being is consciousness (sein ist bewusstsein). Pure panpsychism says that the intrinsic nature of concrete reality is made up of experientiality. It means that energy is experientiality and that is the form of concrete being (Strawson 1994:6).

5. The basic creed of panpsychism is that being is energy, process, quality, mind, and these are all encapsulated by spacetime (Strawson 1994:6). The upshot of this statement is that the universe can be expressed in a single unit of energy. One could also argue that all potential energy of the universe was locked up in the condition just prior to the Big Bang. But since then much has transpired and although the universe may be expressed in a single unit, it presently exhibits diverse modes of being.

\section{Quantum physics and consciousness}

Once the quantum world was accepted as key to reality it was adopted in all possible fields that saw a possibility of renewing their research efforts in terms of the quantum model. Conferences were held and books published on quantum biology, quantum pharmacology, quantum electronics, quantum fluids and solids, quantum gravity and so on.
The quantum idiom is applied to consciousness, metaphysics, ethics (free will) (Suarez \& Adams 2013), theology and the like.

The delayed-choice experiment of Wheeler, which involves a moving object that is given the choice to act like a particle or a wave, refers. Wheeler's experiment asks at which point the object decides which way it will go. Common sense says the object is either wave-like or particle-like, independent of how we measure it. But quantum physics predicts that whether you observe wave-like behaviour (interference) or particle behaviour (no interference) depends only on how it is actually measured at the end of its journey. In a sense measurement creates reality that does not exist if you are not looking at it. If quantum reality is dependent on the observer, it implies that reality is linked to conscious observation (measurement). The question is whether it stops existing when not observed or measured. Is this true only on the quantum level, and do other rules come into play on higher (Newtonian macro) levels?

The hypothesis of a quantum mind and quantum consciousness has been around for some time without producing tangible evidence to work with. The reason for this is, according to Grace (2014:23), the difficulty of mapping one theory (the quantum state of particle physics) onto another (the non-locatable field of consciousness). She refers to field theory to unite matter and consciousness: 'Unified Field Theory suggests the common source of both matter and energy fields (physical and mental forces within the body) as being in an unmanifest quantum field of pure potentiality the unified field of consciousness' (Grace 2014:23). ${ }^{16}$ Adams and Suarez (2013) are bold in their claim that quantum physics and neuroscience are perfectly compatible with consciousness and free will:

these are taken today as basic irreducible principles (axioms) of science. Paraphrasing Guilio Tononi, one could state that consciousness and free will undoubtedly exist, and must be a fundamental ingredient of any sound explanation of the world as fundamental as energy and space-time. (pp. 2587-288)

\section{The participatory panpsychism of Kauffman}

A new panpsychist version of the quantum world has just been proposed by Stuart Kauffman (2016:36ff. See also Kauffman 2015:293-299). Kauffman approaches quantum reality with the distinction between what is possible $e^{17}$ (res potentia) and what is actual (res extensa, as real actuals). The possible and the actual gives rise to one another via measurement (2016:37). But measurement presupposes mind and should have taken place since the Big Bang, long before the appearance of humans. He suggests the possibility of quantum variables that measure one another, perhaps

16.For the analogy between consciousness and information and the way in which information transfer may take place on a quantum level, see Seager and AllenHermanson (2015:15).

17.Kauffman follows CS Peirce in this regard, who argued that actuals and probables do obey the law of excluded middle; possibles do not (Kauffamn 2016:39, $2015: 295$ ). This leads to a new dualism (analogical to the wave-particle dualism) In this dualism, res potentia concerns unmeasured quantum processes (the wave
In In this dualism, res potentia concerns unmeasured quantum processes (the wave
function). Res extensa concerns measured quantum processes (the particle). 
consciously and with free will. 'This will be part of the proposed panpsychism and is, in fact, part of what is called decoherence' (Kaufmann 2015:38). He proposes the triad:

The triad consists in actuals, possibles, and mind measuring possibles, to yield new-in-the-universe actuals. New actuals give rise acausally and instantaneously to new possibles for mind to measure, yielding again new actuals that yield new possibles for mind to measure. Here, nothing is. All is a becoming, all in status nascendi. The role of mind, with consciousness and perhaps free will, is to mediate measurement converting possibles to actuals. Quantum mechanics is about this triad on this view. (Kaufmann 2015:41)

This brings him to a kind of participatory panpsychism. Wherever measurement happens in the universe, via sets of entangled variables, consciousness happens. In this way mind and matter always interact. 'If free will is involved, then the becoming universe depends upon intent.... We then live in a vastly participatory universe' (Kauffman 2015:42). This approach underscores the possibility of a cosmic mind.

\section{Deep incarnation and panpsychism}

One can argue that value is inherent in matter similar to the way that matter also contains information (e.g. its atomic structure). Humans attribute value to matter. On a physical level we distinguish, for example, the atomic weight and number. On the human plane, however, value is determined by what worth humans attribute to an element, be it gold, food or weapons. On this level value may be determined by availability and scarcity, market forces, etc. The question is whether one can distinguish matter itself from its worth and value. Does value 'supervene' on matter similar to the way mind 'supervenes' on brain? Similar distinctions have been made by Whitehead and Jung, who call the ultimate stuff of the world 'energy' (Jung) and 'creativity' (Whitehead). For them everything from electrons to the human psyche embodies this creative energy (Griffin 1989:8).

Humans stand in a very special relation to the matter they are composed of. We are part of the natural world we objectify. Humans themselves are 'thinking matter'. Matter, and this includes all processes that developed over time, comes to 'fruition', to consciousness in humans. It is from this human conscious level that meaning is read back into matter in all various forms and figurations.

What does the cosmic Christ (see Col. 1:9-20) mean if creation is dead, unresponsive material reality? Creation responds to God's decree and does so because it 'experiences' something, recognises and obeys God. Read this against the metaphors personifying nature in the Bible: 'The field is wasted, the land mourneth; for the corn is wasted: the new wine is dried up, the oil languisheth' (Joel 1:10, KJV). Isaiah says of Israel that 'the mountains and the hills before you shall break forth into singing, and all the trees of the field shall clap their hands' (Isa. 55:12). Of course these are metaphors, but they make sense because of the intuitive idea that nature can be personified, is aware and responds to events.
Theological concepts such as logos ensarkos, logos asarkos and kenosis were used to explain incarnation. The nature of God's presence in human form was similar to the question of the presence of Christ's body and blood in the tokens of the Eucharist, where terms such as 'transubstantiation' and 'consubstantiation' were used to make it comprehensible; anhypostasis, enhypostasis had to explain the relation between the two natures of Christ. The concept of perichoresis ${ }^{18}$ ('rotation') was used to describe the relationship between each person in the trinity as well as the relation between God and humans, God and creation, the old and the new, present and future, inner-Trinitarian relations, the presence of Christ's body in the Eucharist and so on. Similar to these challenges, deep incarnation sees God as present in, with and under the many events, processes and experiences in the world of creation. This presupposes panentheistically that all things exist in God. Sheldon (2015:211) describes the incarnation of the eternal into temporal forms. If God joins the biological web of life, suffers in, with and under creation, restores all things in creation, becomes one with creation (all in all) and so on, it is difficult to deny a sense of personification of creation as well as a sense of consciousness, reception and response on the part of creation.

The Christian God 'fits' well into the paradigm of idealism. God as bodiless spirit. Theron (2013:179) writes:

God the creator creates, understanding creation as a mode of free activity. God knows his creation in idea, i.e. as his thinking, and this reflective or self-aware thinking exhausts the content of any possible creation. For nothing can be thought of as being outside God. This is said when one says that God has no real relation to anything outside himself. (p. 179)

If God is a bodiless spirit and all that is exists in Him, then existence is non-material, spirit, idea in the mind of God! This line of thought is not so far removed from the panpsychist notion that everything is consciousness, experience. Back to Theron (2010):

It is in creating that the Trinity utters itself, the word being spoken himself, the Love being born, himself, act. There is no Trinity independently of this. So God speaks and becomes himself with the world as reaching back to him. The world is God's mind and thoughts, his interior where he seeks and finds himself in love ... That is why, also, idealism, absolute idealism, is the only truth, the only philosophy. (p. 180)

Concerning the incarnation Hegel said:

This incarnation of the Divine Being, its having essentially and directly the shape of self-consciousness, is the simple content of Absolute Religion ... In this form of religion the Divine Being is, on that account, revealed. (quoted in Theron 2013:181)

This means that 'in Jesus' God became aware of himself from an opposite, human side. God becomes his own 'Gegenüber' in and through human beings, in and through the human Jesus. It is similar to ask whether reality exists without conscious human beings observing it and interacting with it and whether God exists without acknowledging and worshipping humans. 18.See Lee (2011). 
Gregersen considers the incarnation of God to extend beyond the incarnation in human flesh. It also concerns God's creation. ${ }^{19}$ Flesh in this context is thus extended to include all life. But why stop at all life? What about lifeless matter? What about the quantum world of particle physics? With reference to the quantum world, Kauffman asks whether the universe could possibly be protosentient (Kauffman 2015:302). But this is counter-intuitive. Holmes Rolston III (2015) verbalises this feeling as follows:

Despite what the panpsychists might say, it is hard to put spirit into rocks. That God became flesh in the person of Jesus is already a startling claim, but at least persons - complex, fleshed beings who can think, love, do good and evil - might be the sort of vehicle in which God could become personally present. It is not so with crystals or dirt. (p. 256)

He admits that there is more than one level of indwelling and God can be immanent in dirt without being incarnate in it (Kauffman 2015:263).

Pursuing this argument, he says (Kauffman 2015):

Since God became material in Jesus, did Jesus thereby incarnate all matter, retroactively past, contemporarily present, prospectively future? ... One cannot extrapolate from the particular bit (Jesus' earthly body) to the global whole (Earth, all creation). This is unwarranted slippage. (p. 262)

Gregersen's notion of 'deep incarnation' is the application of aspects of Christology such as incarnation and salvation to the world of nature, reflecting present-day ecological sentiments. We think differently today about nature, the world, the cosmos and our place in it than was the case during the peak of modernism. We realise our interrelatedness with nature; we look with different eyes at our ecologically sensitive planet, and against this background the natural world is filled with values previously reserved for humans.

\section{Conclusion}

Panpsychism endeavours to unite the universe in one grand consciousness. This relates all existence and existing things to each other in some way or another. Humans attach themselves to others (love, care), to things (sentiment), to places (Heimat), to certain times (ritual), events (celebrations), histories (commemoration). We relive the past, personify nature and picture the future. We talk to our pets as if they understand and sometimes experience nature as alive. Children personify their dolls and dinosaurs. Anthropopatically our ancestors worshipped nature as a conscious Gegenüber, to be feared and respected. The need to be part of and to belong ground this sentiment, which is rooted in our biology. We are in principle one with the universe. We owe our existence to the matter formed through cosmic processes. Some feel that the universe 'speaks' to them, enfolds them and 'receives' them back at the end of their lives. This sentiment comes to the fore in panentheism, where our fundamental loneliness is addressed with eternal belonging.

19.Polkinghorne (2015:357) cautions that "a promiscuous use of the concept of incarnation carries with it a dangerous whiff of pantheism'.
Humans seemingly favour unity. We want to relate events and ideas in schemata that make sense. Unity brings closure to isolated existence. We need it. We want things to be one or to be reducible to one basic element. The Greek cosmologists identified one element, such as water or fire or number, to explain everything. Panpsychism sets before us the choice of either consciousness or matter. It is in line with quantum theory to regard the whole cosmos as a web of interacting energies, of spatially and temporally located powers, says Ward (2010:100). Unity gives oversight and control: Ward (2010:89) speculates that what would be impressive as a goal of the universe would be the following the genesis of a consciousness, or perhaps a society of consciousnesses, that understood and could control the cosmos itself, which could devise endless creative purposes and experience unlimited types of intensities and feeling'.

Terms such as consciousness, energy and experience are not precisely interchangeable. Consciousness may be a form of energy but all energy is not conscious. Dasein may translate into Sosein but all forms of Sosein do not have Dasein. To a large degree panpsychism depends on the notion of 'whatis-it-like' to be something, to experience something, etc. Because this cannot be known we cannot attribute characteristics to different forms of 'what-is-it-like-ness', endowing it with some form of mentality, self-feeling or selfknowing abilities.

Consciousness is too complex a phenomenon to use generically. Human consciousness includes language ability and cognitive skills. It differs dramatically from animal consciousness and what can be called awareness in the case of lower organisms. Consciousness is 'manifested' differently in different individuals. To move from human consciousness to animal consciousness and to the forms of awareness that constitute lower organisms constitutes a huge leap. Crossing the border into the territory of lifeless matter brings us into the sphere of the speculative. But we do not consider our existence as speculative, and this would not have been possible without lifeless matter.

Panpsychism displays traces of vitalism, personification and anthropopathism. ${ }^{20}$ Panpsychism states that all matter has experience because matter matters, i.e. it works, interacts, makes history. This ineluctably implies consciousness. But it makes no sense that dead matter has consciousness, memory or history. The presence of a god or the mind or the memory of God in and under matter (perichoresis) may make such an option possible. This translates into 'deep incarnation'.

The crucial question is: does 'having a history' equal 'knowing' your history (i.e. consciousness)? Does the particle that hops into existence and then collapses again, know or remember it? For Strawson, when it comes to experience, the having is the knowing (Strawson 2015:18).

20.The term kenosis has been applied to non human and even inanimate matter to indicate how lower physical systems support higher systems and how some forms af life serve others. In this way the human trait of altruism is an some forms of life serve others. In this way the human trait of altruism is anthropopatically conferred on natural processes and non-human forms of life, which comes close to the attribution of mind to non-human entities. 
Perhaps panpsychism must be valued positively in the light of the new ecological sentiments that have developed over the last decade. Deep ecology triggers deep incarnation, said John Haughey (quoted in Holmes Rolston III 2015:273). In the same breath one could say that deep ecology also triggers panpsychism.

We need to ask why some theologians want to extend God's incarnation and grace beyond the human. The easy answer is that it makes us feel good. Holmes Rolston III (2015:272) asks: 'Could there be a danger here of believing the absurd? This is a blanket claim that does not know what it covers, but it feels good to make such claims of solidarity with all creation'.

With the 'non-human turn' we humans have entered a new phase of interaction with matter, i.e. our environment, our planet and its place in the cosmos. This entails a new kind of awareness that may prove to be vital to the future existence of the human species.

\section{Acknowledgements Competing interests}

The author declares that he has no financial or personal relationships which may have inappropriately influenced him in writing this article.

\section{References}

Adams, P. \& Suarez, A., 2013, 'Exploring free will and consciousness in light of quantum physics and neuroscience', in P. Adams \& A. Suarez (eds.), Is science compatible with free will? Exploring free will and consciousness in the light of quantum physics and neuroscience, pp. 273-290, Springer, New York.

Aizawa, K., 2010, 'Consciousness: Don't give up on the brain', in P. Basile, J. Kiverstein \& P. Phemister (eds.), The metaphysics of consciousness, pp. 263-284, Cambridge University Press, Cambridge.

Barnard, W.G., 2011, Living consciousness. The metaphysical vision of Henri Bergson, State University of New York, New York.

Basile, P., Kiverstein, J. \& Phemister, P. (eds.), 2010, The metaphysics of consciousness, Cambridge University Press, Cambridge.

Carroll, S., 2012, The particle at the end of the universe, One World, London.

Clark, S.R.L., 2010, 'How to become unconscious', in P. Basile, J. Kiverstein \& P. Phemister (eds.), The metaphysics of consciousness, pp. 21-44, Cambridge University Press, Cambridge.

Cooper, J.W., 2006, Panentheism. The other God of the philosophers, Baker, Grand Rapids, MI.

Deane-Drummond, C., 2009, 'Are animals moral? Taking soundings through vice, virtue, conscience and Image Dei', in C. Deane-Drummond \& D. Clough (eds.), Creaturely theology, pp. 190-210, SCM, London.

Grace, D.M., 2014, Beyond bodies: gender, literature and the enigma of consciousness, Rodopi B.V., Amsterdam.
Griffin, D.R., 1989, 'Archetypal psychology and process philosophy: Complementary postmodern movements', in D.R. Griffin (ed.), Archetypal process, pp. 1-77, Northwestern University, Evanston, IL.

Grusin, R. (ed.), 2015, The nonhuman turn, University of Minnesota Press, Minneapolis, MN

Hacker, P.M.S., 2013, The intellectual powers. A study of human nature, Wiley Blackwell, Oxford.

Holmes, R., III, 2015, 'Divine presence - Causal, cybernetic, caring, cruciform: From information to incarnation', in N.H. Gregersen (ed.), Incarnation, pp. 255-288, Fortress, Minneapolis, MN.

Holt, J., 2012, Why does the world exist? Liveright, New York.

Kauffman, S., 2015, 'Natural incarnation: From the possible to the actual', in N.H. Gregersen (ed.), Incarnation, pp. 289-308, Fortress, Minneapolis, MN.

Kauffman, S., 2016, 'Cosmic mind?', Theology and the Science 14(1), 36-47. http://dx.doi.org/10.1080/14746700.2015.1122324

Krämer, M., 2015, 'The philosophy of the Large Hadron Collider', Guardian UK, 6 June. https://www.theguardian.com/science/life-and-physics/2015/jun/06/thephilosophy-of-the-large-hadron-collider

Lee, B.J., 2011, Celebrating God's cosmic perichoresis. The eschatological panentheism of Jürgen Moltmann as a resource for an ecological Christian worship, Pickwick, Eugene, OR.

Low, P., 2012, 'The Cambridge declaration on consciousness', in J. Panksepp, D. Reiss, D. Edelman, B. van Swinderen, P. Low \& C. Koch (eds.), Presented at the Francis Crick Memorial Conference, University of Cambridge.

McHenry, L., 2010, 'Sprigge's ontology of consciousness', in P. Basile, J. Kiverstein \& P. Phemister (eds.), The metaphysics of consciousness, pp. 5-20, Cambridge University Press, Cambridge.

Nagel, T., 1974, 'What is it like to be a bat?', The Philosophical Review, LXXXIII, 435-450.

O'Murchu, D., 2004, Quantum theology. Spiritual implications of New Physics, Crosssroads, New York.

Peters, T., 2016, 'The cosmic mind: Entanglement over physics, panpsychism and the Trinity', Theology and the Science, 14(1), 1-5. http://dx.doi.org/10.1080/14746700. 2015.1122324

Polkinghorne, J., 2015, 'Afterword: Reservations', in N.H. Gregersen (ed.), Incarnation, pp. 355-360, Fortress, Minneapolis, MN.

Seager, W. \& Allen-Hermanson, S., 2015, 'Panpsychism', in E.N. Zalta (ed.), The Stanford Encyclopedia of Philosophy, Fall Edition, viewed 23 July 2015, from http://plato.stanford.edu/archives/fall2015/entries/panpsychism/

Shaviro, S., 2015, 'Consequences of panpsychism', in R. Grusin (ed.), The nonhuman turn, pp. 19-44, University of Minnesota Press, Minneapolis, MN.

Sheldon, R., 2015, 'Form/matter/chora', in R. Grusin (ed.), The nonhuman turn, pp. 193-222, University of Minnesota Press, Minneapolis, MN.

Strawson, G., 1994, Mental reality, MIT, Cambridge, MA.

Strawson, G., 2015a, 'Mind and being: The primacy of panpsychism', in G. Bruntrup \& L. Jaskolla (eds.), Panpsychism: Philosophical essay, pp. 1-35, Oxford University Press, Oxford.

Strawson, G., 2015b, 'Real materialism', in T. Alter \& Y. Nagasawa (eds.), Consciousnes in the physical world: Perspectives on Russellian monism, pp. 161-208, Blackwell, Oxford.

Suarez, A. \& Adams, P. (eds.), 2013, Is science compatible with free will? Exploring free will and consciousness in the light of quantum physics and neuroscience, Springer, New York.

Theron, S., 2013, Reason's developing self-revelation. Tradition in the crucible of Absolute Idealism, Cambridge Scholars, Newcastle-upon-Tyne, UK.

Trigg, R., 2015, Beyond matter: Why science needs metaphysics, Nautilus, Oxford.

Ward, K., 2010, More than matter? Eerdmans, Cambridge.

Wolchover, N., 2014, 'A new physics theory of life', Scientific American, viewed August 2015, from http://www.scientificamerican.com/article/a-new-physics-theory-of life/ 